\title{
PHF11 expression and cellular distribution is regulated by the Toll-Like Receptor 3 Ligand Polyinosinic:Polycytidylic Acid in $\mathrm{HaCaT}$ keratinocytes
}

Pauline Muscat ${ }^{1 \dagger}$, Karessa Mercado $^{1 \dagger}$, Kathryn Payne $^{2}$, Hardip Chahal $^{1}$ and Graham Jones ${ }^{{ }^{*}}$

\begin{abstract}
Background: Inflammatory skin diseases such as atopic dermatitis and psoriasis represent a complex interaction between the skin and infiltrating immune cells, resulting in damage to the skin barrier and increased inflammation. Polymorphisms in PHF11 have been associated with dermatitis and allergy and PHF11 regulates the transcription of T-cell cytokines as well as class switching to lgE in activated B-cells. The importance of skin barrier homeostasis in the context of inflammatory skin diseases, together with reports identifying PHF11 as an interferon-induced gene, have led us to examine its role in the innate immune response of keratinocytes.

Results: We developed a cell culture model that allowed us to analyze the effects of the double-stranded RNA analogue poly(l:C) on a confluent cell monolayer immediately after a 24-h treatment, as well as three days after withdrawal of treatment. Immediately after treatment with poly(I:C), PHF11, IL8, and interferon-dependent ISG15 RNA expression was increased. This was accompanied by nuclear localization of PHF11 as well the tight junction protein claudin-1. Knock-down of PHF11 resulted in increased interleukin-8 expression and secretion immediately following treatment with poly $(\mathrm{l}: \mathrm{C})$, as well as changes in the cellular distribution of membrane-bound and increased nuclear claudin-1 that was observed up to 3 days after the withdrawal of poly(l:C). This was associated with lower cell density and a decrease in the number of cells in the G1 phase of the cell cycle.
\end{abstract}

Conclusions: In addition to a role for PHF11 in lymphocyte gene expression, we have now shown that PHF11 was part of the keratinocyte innate immune response by poly(l:C). As knock-down of PHF11 was associated with increased expression of the pro-inflammatory chemokine IL-8 and changes in the cellular distribution of claudin-1, a change normally associated with increased proliferation and migration, we suggest that PHF11 may contribute to epidermal recovery following infection or other damage.

Keywords: PHF11, keratinocyte, HaCaT, poly(l:C), TLR3, claudin-1

\section{Background}

Plant homoeodomain finger protein 11 (PHF11) is highly expressed in circulating immune cells, with increased expression in T-helper 1 (Th1) T-cells relative to Th2 Tcells [1]. Knock-down of PHF11 using small interfering RNA (siRNA) decreases expression of the interferon- $\gamma$ (IFNG) gene in Th1 cells [1] through a mechanism that

\footnotetext{
* Correspondence: graham.jones@uws.edu.au

${ }^{\dagger}$ Equal contributors

'School of Science and Health, Western Sydney University, Locked Bag 1797, 2751 Penrith, NSW, Australia

Full list of author information is available at the end of the article
}

involves a reduction in NFkB-dependent transcriptional activity $[1,2]$. A role for PHF11 in IFNG gene expression, and more recently the finding that PHF11 increases class switch recombination to IgE in murine B-cells [3], supports a role for PHF11 in allergic disease. A link between PHF11 and allergic disease was shown in earlier genetic linkage and association studies [4-6], with alternate alleles of a single nucleotide polymorphism in the 3' nontranslated exon of PHF11 associated with a change in the expression of this gene in Th1 cells [1] through differential binding of the transcription factor Oct-1 [7]. 
Although recent genome-wide association studies (GWAS) of asthma and atopic dermatitis have not supported a genetic association between PHF11 and allergy, it remains possible that there may be an association in selected cohorts of severely affected individuals who show a very early age of onset with highly elevated IgE levels and who are more likely to require treatment by specialist clinicians [8].

Allergic asthma and dermatitis are characterized by immune sensitization, which refers to the initial recognition of an antigen by the immune system and the production of antigen-specific IgE antibodies. In susceptible individuals any subsequent exposure to the same allergen will result in a robust and aggressive immune response. It is now apparent that there is a link between immune sensitization and the integrity of the skin barrier. As an example, filaggrin is a protein found in the outermost layer of the epidermis called the stratum corneum and is essential for the integrity of the skin barrier (for review, see [9]). Mutations in the gene encoding filaggrin $(F L G)$ are associated with immune sensitization in allergic dermatitis and asthma $[10,11]$ and these mutations cause an impairment of the skin barrier function $[12,13]$. Genetic association between a locus containing the gene C11orf30 is highly reproduced in GWAS of asthma and dermatitis [14-16], and although the functional relationship between C11orf30 or other nearby genes with asthma and dermatitis is not understood, the protein product of C11orf30 (EMSY) is important in epithelial tumours of the breast and ovary $[17,18]$.

In addition to a genetic basis for a compromised skin barrier, elevated expression of Th2-type cytokines such as interleukin (IL)-4 and IL-13 in the skin of individuals with atopic dermatitis decreases filaggrin expression [19]. These cytokines also decrease the expression of the tight junction protein claudin-1 in the skin of individuals with atopic dermatitis [20]. The combination of genetic and inflammatory triggers that result in a decrease in the integrity of the skin barrier are also linked to the high rate of bacterial and viral skin infections of individuals with atopic dermatitis [21, 22]. Keratinocytes express several members of the Toll-like Receptor (TLR) family that are pattern recognition receptors for viral and bacterial pathogens. The TLR3 recognizes double-stranded RNA that is a replication intermediate for a number of viruses, as well as RNA that is released from damaged cells. Activation of TLR3 is an important part of the keratinocyte innate immune response [23], as well as the repair and maintenance of the skin barrier $[24,25]$.

A review of the literature revealed that PHF11 is an interferon stimulated gene (ISG) and that its expression is increased following infection by several different viruses [26-29]. Although previous functional studies of PHF11 have centered on its role in the regulation of cytokine gene expression in T-lymphocytes $[1,2]$, the susceptibility of individuals with atopic dermatitis to viral infection and the finding that PHF11 is an ISG has led us to test for PHF11 expression in keratinocytes and whether its expression is regulated by polyinosinic:polycytidylic acid (poly(I:C)), a ligand for TLR3 and an analogue of double-stranded RNA.

In this study we report that PHF11 is expressed in the human $\mathrm{HaCaT}$ keratinocyte cell line and that treatment of this cell line with the double-stranded RNA (dsRNA) analogue poly(I:C) resulted in an increase in PHF11 expression and the localization to the nucleus of the PHF11 protein. Furthermore, siRNA knock-down of PHF11 mRNA resulted in a loss of PHF11 from the nucleus and this was accompanied by an increase in IL- 8 expression, altered appearance of claudin-1 at the cell membrane and the appearance of claudin- 1 in the nucleus. We suggest that in addition to its role in circulating T-cells, PHF11 also plays a role in the innate immune response of keratinocytes and that a reduction in PHF11 expression may contribute to inflammation and tissue remodeling following infection or tissue damage.

\section{Methods \\ Cell culture}

$\mathrm{HaCaT}$ Keratinocytes were grown in a complete cell culture medium consisting of Dulbecco's Modified Eagle Medium (DMEM) and $10 \%$ fetal bovine serum (FBS) at $37{ }^{\circ} \mathrm{C}$ in a humidified atmosphere containing $5 \% \mathrm{CO}_{2}$.

\section{CDNA synthesis and quantitative real-time PCR}

Total RNA was harvested using the PureLink ${ }^{\circ}$ RNA Mini kit (Ambion $\%$ Life TechnologiesTM, Austin, TX, USA) and cDNA was synthesized from $1 \mu \mathrm{g}$ of RNA using the Applied Biosystems High-Capacity cDNA Reverse Transcription Kit according to the manufacturers instructions. Quantitative real-time PCR was done using $\mathrm{SYBR}^{\circ} \mathrm{PCR}$ Master Mix (Applied Biosystems, Austin, TX, USA), $0.1 \mu \mathrm{M}$ of forward and reverse primers in a final volume $10 \mu \mathrm{l}$. Reactions were transferred to an Illumina Eco 48-well plate and analysed using an Illumina ${ }^{\circ}$ Eco real-time PCR system. Primer sequences are shown in Table 1.

\section{siRNA knockdown}

All siRNAs have been previously tested and validated [2]. The sequence of PHF11-specific siRNAs are: siRNA siRNA_1 CACCGTGGGATGTGATTTAAA (Qiagen, Hilden, Germany, cat no. SI00113554) and siRNA_5 ATCATCGCTCAAAGTGCTAAA (Qiagen, cat no. SI0 3047198), mapping to exons 4 and 5 of PHF11 isoform NM_001040443.1, respectively. On the day of transfection, $\mathrm{HaCaT}$ keratinocytes were harvested and resuspended at a concentration of $1 \times 10^{5}$ cells in $300 \mu \mathrm{l}$ of complete cell culture media. $600 \mathrm{ng}$ of siRNA was diluted in $100 \mu \mathrm{l}$ of Optimem culture media (Gibco $\%$ Life Technologies, Austin, 
Table 1 Primers used for Quantitative real-time PCR

\begin{tabular}{|c|c|c|}
\hline \multirow[t]{2}{*}{ Primer } & \multirow[t]{2}{*}{ Product size (bp) } & Sequence $\left(5^{\prime}-3^{\prime}\right)$ \\
\hline & & Forward (F), Reverse (R) \\
\hline \multirow[t]{2}{*}{ Claudin-1 } & \multirow[t]{2}{*}{109} & F: GGTCAGGCTCTCTTCACTGG \\
\hline & & R: GCCTTGGTGTTGGGTAAGAG \\
\hline \multirow[t]{2}{*}{ IL-8 } & \multirow[t]{2}{*}{109} & F: TCTGCAGCTCTGTGTGAAGG \\
\hline & & R: AAATTTGGGGTGGAAAGGTT \\
\hline \multirow[t]{2}{*}{ ISG15 } & \multirow[t]{2}{*}{97} & F: AGCATCTTCACCGTCAGGTC \\
\hline & & R: GAGAGGCAGCGAACTCATCT \\
\hline \multirow[t]{2}{*}{ KRT10 } & \multirow[t]{2}{*}{91} & F: CCTGGCTTCCTACTTGGACA \\
\hline & & R; TTGCCATGCTITCATACCA \\
\hline \multirow[t]{2}{*}{ KRT14 } & \multirow[t]{2}{*}{90} & F: TCCTCAGGTCCTCAATGGTC \\
\hline & & R: CGACCTGGAAGTGAAGATCC \\
\hline \multirow[t]{2}{*}{ KRT1 } & \multirow[t]{2}{*}{110} & F: CAACCAGAGCCTTCTTCAGC \\
\hline & & R: AGGAGGCAAATTGGTTGTTG \\
\hline \multirow[t]{2}{*}{ PHF11 } & \multirow[t]{2}{*}{140} & R: TCCTGCTTCCTTGCATTTCT \\
\hline & & F: GGAAGGAAGAAACCCCTCTC \\
\hline \multirow[t]{2}{*}{ SDHA } & \multirow[t]{2}{*}{86} & F: TGGGAACAAGAGGGCATCTG \\
\hline & & R: CCACCACTGCATCAAATTCATG \\
\hline
\end{tabular}

TX, USA), followed by the addition of $6 \mu$ of Hiperfect ${ }^{\circ}$ Transfection reagent (Qiagen, Hilden, Germany). Following a $10 \mathrm{~min}$ incubation at room temperature, the siRNA mixture was combined with the $\mathrm{HaCaT}$ cells and plated directly onto 24 -well plates $\left(1 \times 10^{5}\right.$ cells/well $)$ or an 8-well Nunc ${ }^{\circ}$ Lab-Tek $^{\oplus}$ Chamber slide $\left(5 \times 10^{4}\right.$ cells/ well) and incubated overnight at $37{ }^{\circ} \mathrm{C} / 5 \% \mathrm{CO}_{2}$. The transfection solution was then replaced with complete cell culture medium and the cells were returned to the incubator for a further 2 days, and then treated with poly $(\mathrm{I}: \mathrm{C})$ for $24 \mathrm{~h}$. Cells were harvested either 24 or $96 \mathrm{~h}$ after treatment with poly(I:C).

\section{HEK Cell transfection and PHF11 expression plasmids}

Full-length PHF11 cDNA was cloned into the plasmid expression vector pEGFP-C1 (Clontech) and was then used as a template to generate the two C-terminal deletion constructs del218 and del165 that terminate at valine residue 218 and alanine residue 165, respectively. Numbering of amino acids is based on NCBI reference sequence NP_001035533.1. Transfection of HEK cells was done as previously described [1]. Identification of a putative nuclear localization sequence was done using the following online tool: http://nls-mapper.iab.keio.ac.jp/cgi-bin/ NLS_Mapper_form.cgi. Western blot analysis confirmed that each recombinant protein was expressed at the predicted molecular weight (data not shown). Images were analysed using ImageJ (http://imagej.nih.gov/ij/).

\section{Immunofluorescence}

In experiments to visualize IL-8 production, $0.5 \mathrm{mM}$ Monensin sodium salt (Sigma, St. Louis, USA) was added to the culture media and cells returned to $37{ }^{\circ} \mathrm{C} / 5 \% \mathrm{CO}_{2}$ for the final $4 \mathrm{~h}$ of stimulation by poly(I:C) [30]. To visualize IL-8, as well as claudin-1 and PHF11, cells were fixed in a $4 \%$ formaldehyde solution for $10 \mathrm{~min}$ at room temperature, washed and permeabilized by washing for $3 \times 5 \mathrm{~min}$ in PBS/0.01\% Triton X100. Cells were then blocked in Image-i $T^{\mathrm{m}}$ FX Signal Enhancer (Molecular Probes, Oregon, USA) for $30 \mathrm{~min}$ and washed a further $3 \times 5$ min in PBS/0.01\% Triton X100. The cells were incubated with the following primary antibodies in blocking buffer (1\%BSA, $0.01 \%$ Triton X100, $5 \%$ FCS in PBS) overnight at $4{ }^{\circ} \mathrm{C}$ : rabbit anti-Claudin 1 (1:1000, Sigma-Aldrich, SAB4503546), rabbit anti-PHF11 (1:100, ProteinTech Group, 10898-1-AP), mouse antiCXCL8/IL-8 (10 $\mu \mathrm{g} / \mathrm{ml}, \mathrm{R} \& \mathrm{D}$ systems, MAB208). Cells were then washed for $3 \times 5 \mathrm{~min}$ in PBS/0.01\% Triton X100 and then incubated with a 1:1000 dilution Alexa Flour ${ }^{\circ} 488$ goat anti-rabbit IgG $(\mathrm{H}+\mathrm{L})$ and/or a 1:1000 dilution of Alexa Flour 555 goat anti-mouse IgG $(\mathrm{H}+\mathrm{L})$ (Molecular probes/Life Technologies ${ }^{\mathrm{Tm}}$, Austin, TX, USA) in blocking buffer at room temperature for $1 \mathrm{~h}$ in the dark. Cells were washed $2 \times 5 \mathrm{~min}$ in PBS/0.01\% Triton X100, and nuclear DNA was stained using a solution of $1 \mu \mathrm{g} / \mathrm{ml}$ Hoechst 33342 (Molecular probes/Life Technologies ${ }^{\mathrm{Th}}$, Austin, TX, USA) for $10 \mathrm{~min}$ at room temperature protected from light. After a final 5 min wash in PBS/0.01\% Triton X100, 2 drops of ProLong ${ }^{\circ}$ Gold antifade reagent was added to the slide and covered with a glass cover slip. Slides were viewed on an Olympus BX43 Microscope fitted with an X-Cite Series 120Q EXFO Halogen Lamp using cellSens standard software or using a TCS-SP5 confocal microscope (Leica Microsystems, Germany).

\section{IL-8 enzyme-linked immunosorbent assay (ELISA)}

Cells were transfected with siRNA as described and $1 \times 10^{4}$ cells were plated per well in a 96-well plate in triplicate. Following $24 \mathrm{~h}$ treatment with poly(I:C), the concentration of secreted IL-8 was determined using the Human CXCL8/IL-8 Quantikine ELISA (R \& D Systems, MN, USA, Cat no. D8000C). The amount of secreted IL-8 was normalized to cell number using the CyQUANT NF Cell Proliferation Assay Kit (Molecular probes/Life Technologies ${ }^{\mathrm{Tw}}$, Austin, TX, USA). Results represent the outcome of 4 independent siRNA transfections.

\section{Cell cycle analysis}

At the conclusion of an experiment, cell culture media was removed and the cells harvested using trypsin. Cells were washed once in $5 \mathrm{ml}$ of PBS, and then resuspended and fixed in $5 \mathrm{ml}$ of $70 \%(\mathrm{v} / \mathrm{v})$ ethanol (Sigma-Aldrich) at $4{ }^{\circ} \mathrm{C}$ for up to 7 days. Following fixation, cells were 
centrifuged at $300 \times \mathrm{g}$ for $5 \mathrm{mins}$ at room temperature, washed in PBS, and then resuspended in a solution of $1 \mu \mathrm{l}$ RNase, $2 \mu \mathrm{l}$ 10x propidium iodine (PI) (Sigma-Aldrich) in PBS and incubated at $37{ }^{\circ} \mathrm{C}$ for $50 \mathrm{~min}$. Cells were then collected by centrifugation at $300 \times \mathrm{g}$ for $5 \mathrm{~min}$ at room temperature and the cell pellet resuspended in $1 \mathrm{ml}$ of PBS. Samples were analysed using a FACSCanto II (BD Bioscience, Franklin Lake NJ, USA). Ten thousand events were collected per sample and data was exported and analysed using FlowJo Flow Cytometry Analysis Software 7.6.5 (Tree Star, Ashland, OR, USA). A scatterplot was created and the region containing the G1, S and G2/M peaks was gated to select singlet cells. A histogram of the gated region was produced and live cells as well as sub-G1 cells were defined. Cell cycle analysis was done using the Dean-Jett-Fox model.

\section{Results}

Poly $(\mathrm{I}: \mathrm{C})$ increased the expression and nuclear localization of PHF11

The $\mathrm{HaCaT}$ cell line was used to test whether poly(I:C) regulates the expression of PHF11 in keratinocytes. The induction of interferon signaling by poly(I:C)-dependent activation of toll-like receptor 3 (TLR3) has previously been reported in this cell line $[23,31]$. Since poly(I:C) is able to activate innate immune signaling pathways as well as induce apoptosis [32], we were interested in examining the regulation of PHF11 to poly(I:C) at 1 and 3 days after the commencement of treatment.

To do this, HaCaT keratinocytes were cultured for 3 days to reach a confluent monolayer and then treated for 24-h with poly(I:C). Cells were either analyzed immediately (i.e., $24 \mathrm{~h}$ after commencing treatment; a total of 4 days in culture) or poly(I:C) was removed and cells cultured for a further 3 days, making a total of 7 days in culture (Fig. 1).

Analysis of gene expression $24 \mathrm{~h}$ after commencing treatment with $1 \mu \mathrm{g} / \mathrm{ml}$ of poly(I:C) showed an approximately 4-fold increase in PHF11 RNA (Fig. 2a, $1 \mu \mathrm{g} / \mathrm{ml}$
poly(I:C), 4 days in culture) relative to untreated cultures. Three days after withdrawal of poly(I:C), expression of PHF11 had declined to be no different from cultures not treated with poly(I:C) (Fig. $2 \mathrm{a}, 1 \mu \mathrm{g} / \mathrm{ml}$ poly(I:C), 7 days in culture). There was no change in the expression of RNA encoding the tight junction marker claudin-1 (CLDN1) between different treatment conditions (Fig. 2a, CLDN1). To confirm that the cells had responded to poly(I:C), we also analyzed the expression of genes encoding interleukin (IL)-8 and ISG15, both of which are regulated by poly(I:C) $[33,34]$. Analysis of RNA expression immediately after $24 \mathrm{~h}$ of treatment with poly(I:C) showed IL8 was increased by more than 140-fold while ISG15 expression was increased approximately 20-fold (Fig. 2b, $1 \mu \mathrm{g} / \mathrm{ml}$ poly(I:C), 4 days in culture). Analysis of RNA expression three days after withdrawal of poly(I:C) showed ISG15 expression had declined to levels not different from untreated cultures, while IL8 RNA remained approximately 50-fold higher than that seen in untreated controls (Fig. 2b, IL8, 7 days in culture).

As the activation of TLR3 can promote skin barrier repair [25], we also looked for changes in the expression of keratin genes that are normally active in undifferentiated keratinocytes (keratin 14) or in keratinocytes during early differentiation (keratins 1 and 10). After 3 days in culture, treatment for $24 \mathrm{~h}$ with poly(I:C) did not change the expression of keratin-14, although the expression of both keratin-1 and -10 were decreased 2.5 to 3 -fold under the same conditions (Fig. 2c, 4 days in culture). Assaying the expression of each keratin gene three days after the withdrawal of poly(I:C) revealed a significant decrease in the expression of keratin-14, independently of poly(I:C) treatment (Fig. 2c, 7 days in culture), whereas the expression of keratin-1 and keratin-10 were either not different from untreated controls or showed only a small increase in expression, respectively (Fig. 2c).

We have previously shown that in Jurkat T-cells PHF11 localization is mainly cytoplasmic, although stimulation with PMA/ionomycin increases the amount of PHF11

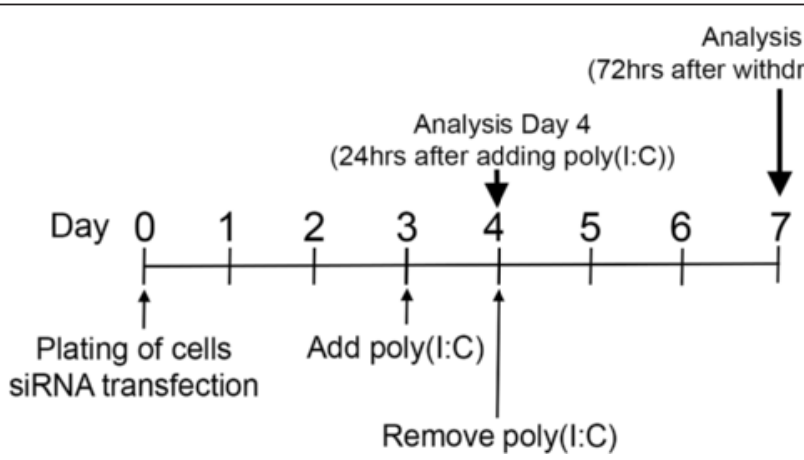

Fig. 1 Summary of siRNA transfection and culturing of HaCaT keratinocytes. Cells were cultured for up to 7 days, with poly(l:C) treatment commencing on day 3 of culture for $24 \mathrm{~h}$. Cells were analyzed immediately after treatment, or were washed and cultured for a further 3 days. Transfection with siRNA was done on the day of plating 

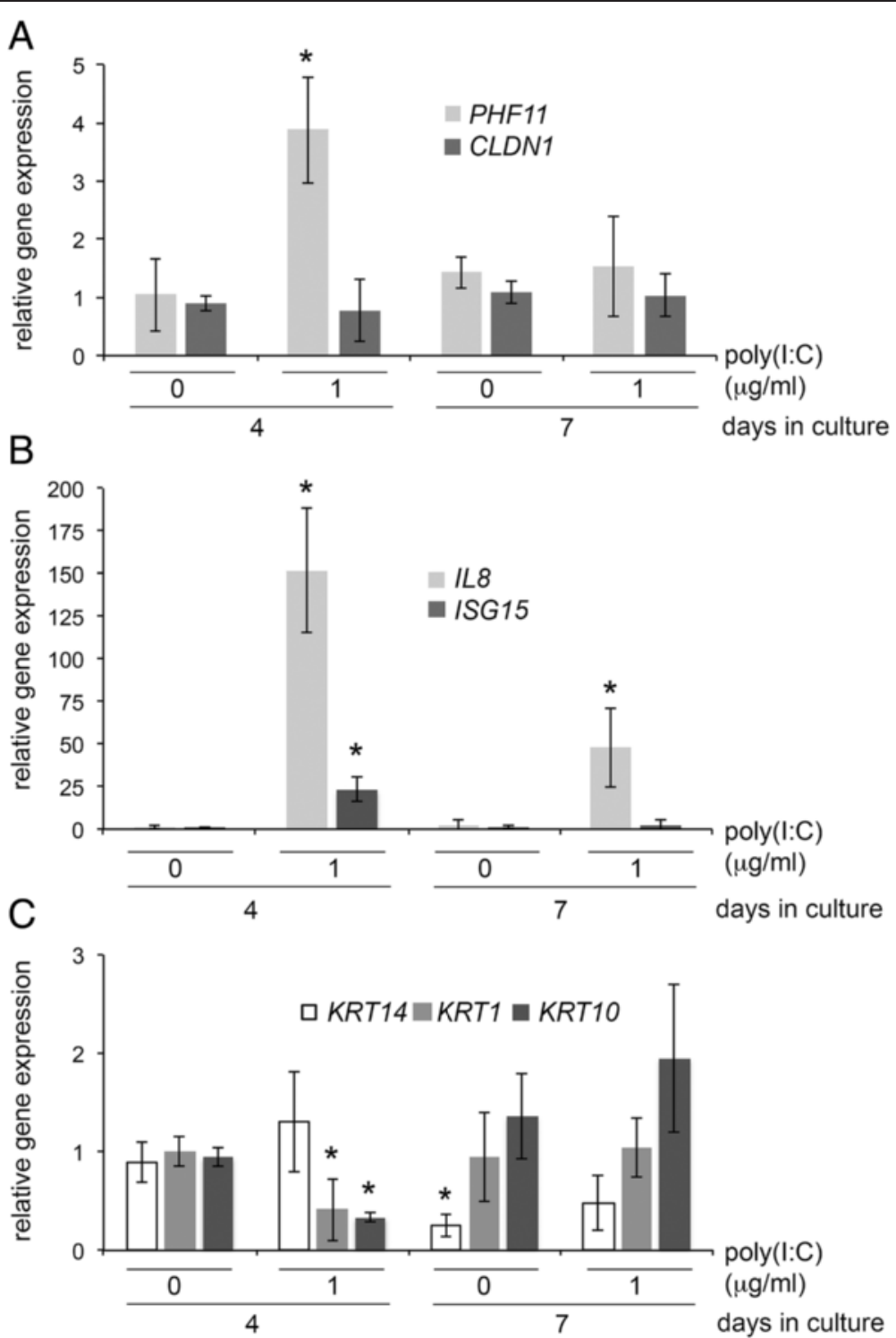

Fig. 2 Profile of gene expression in HaCaT keratinocytes in response to poly (l:C) at 4 and 7 days in culture. Cells were left untreated or treated with $1 \mu \mathrm{g} / \mathrm{ml}$ of poly $(\mathrm{l}: \mathrm{C})$ on day 3 and harvested on day 4 or on day 7. Quantitative real-time PCR was used to analyse the expression of PHF11, claudin-1 (CLDN1), IL-8 (IL8), interferon-stimulated gene 15 (ISG15) and keratins 1, 14 or 10 (KRT1, 10, 14). Results represent 4 independent experiments. Bars indicate average \pm standard deviation, asterisks indicate significant difference relative to control $(p<0.05$, Mann-Whitney U-test)

in the nucleus [2]. In $\mathrm{HaCaT}$ keratinocytes, nuclear localization of PHF11 was strongly increased following a $24 \mathrm{~h}$ incubation with poly(I:C) (Fig. 3a). Three days after withdrawal of poly(I:C) the nuclear localization of PHF11 had decreased and, similar to untreated cultures, showed strong cytoplasmic localization (data not shown). The distribution of PHF11 in the nucleus had a highly speckled or punctate appearance and differed from nuclear distribution of NF-kB (Fig. 3b).

The stimulus-dependent nuclear localization of PHF11 led us to search for sequences that control its cellular localization. To do this, we first searched for possible nuclear localization sequences (NLS) using an online mapping tool (cNLS Mapper) [35]. This identified a putative monopartite NLS beginning at residue 172 and consisting of the sequence SGVKRKRGRK (Fig. 4a). Next, full-length PHF11 as well as two C-terminal deletion mutants that terminate at amino acids 218 and 169 (Fig. 4a) were cloned into a green fluorescent protein (GFP) expression vector. Transfection of human embryonic kidney (HEK) cells showed that the expressed fulllength protein was present in the cytoplasm, as well as in a speckled pattern in the nucleus (Fig. 4b, full-length). Deletion to amino acid 218, which retained both the 

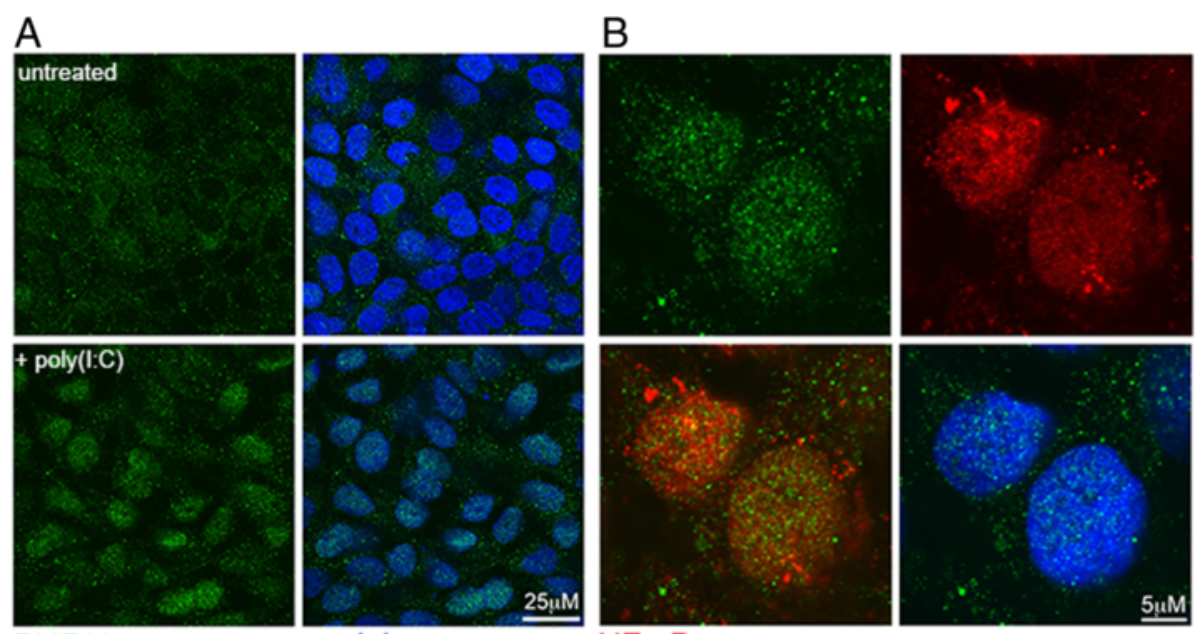

PHF11

nuclei

$\mathrm{NF}-\kappa \mathrm{B}$

Fig. 3 Nuclear localization of PHF11 is induced by poly(l:C). a Confocal microscopy of PHF11 localization in HaCaT keratinocytes on day 4 of culture in the absence of poly $(I: C)$ (untreated), or after a 24-h poly $(I: C)$ treatment (+poly $(l: C))$. $\mathbf{b}$ Higher magnification image of the nuclei of cells treated with poly(l:C) and stained for PHF11 (green), NF-KB (red). A merged image of PHF11 and NF-KB (lower left), as well as DAPI-stained nuclei (lower right) is shown

PHD domain as well as the putative NLS, resulted in nuclear localization (Fig. 4b, del218). However, the PHF11 deletion mutant that terminated at residue 169 and lacked the putative NLS also showed strong nuclear localization (Fig. 4b, del169). These results showed that the deletion of sequences in the C-terminal half of PHF11 between amino acids 218 and 331, but not of a sequence rich in basic residues located between residues 172 and 181, resulted in nuclear localization of PHF11.
siRNA knock-down of PHF11: analysis immediately after poly $(\mathrm{l}: \mathrm{C})$ treatment

To explore the role of PHF11 in keratinocytes, $\mathrm{HaCaT}$ cells were treated with siRNA that has previously been used to successfully knock-down PHF11 expression in Tcells [2]. In HaCaT cells transfected with a control siRNA and treated with poly(I:C), PHF11 immunoreactivity was clearly visible in nuclei after $24 \mathrm{~h}$ of treatment with poly(I:C) (Fig. 5, siCon). Under the same conditions, transfection of HaCaT cells with PHF11-specific siRNA resulted

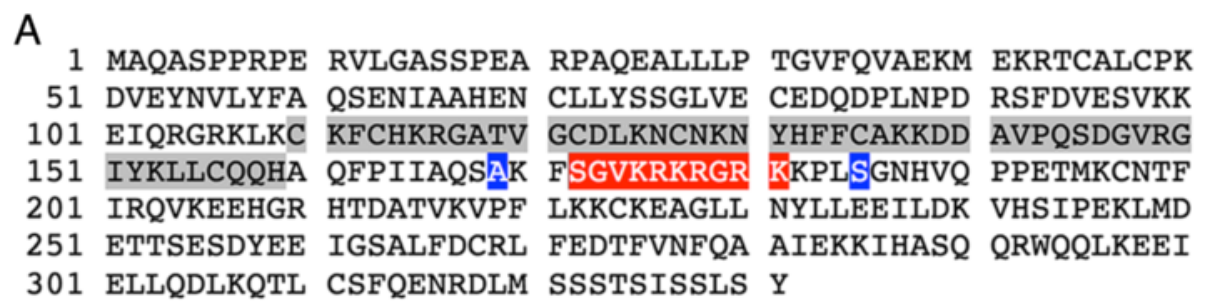

B
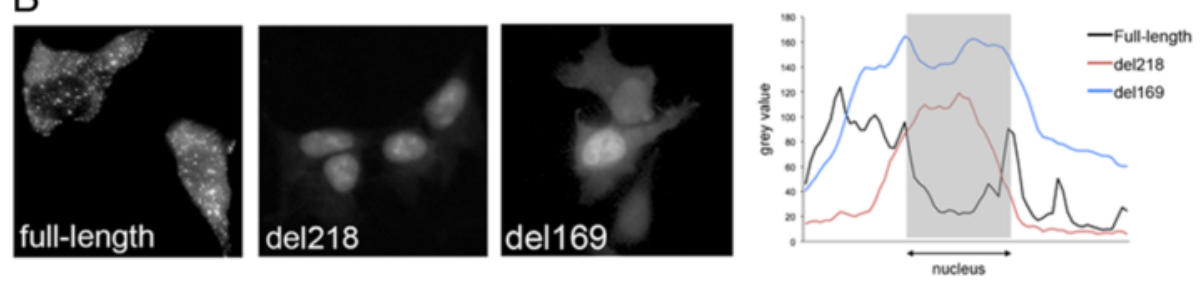

Fig. 4 C-terminal deletion mutants of PHF11 are localized in the nucleus. a The amino acid sequence of PHF11 showing the PHD domain (grey highlight), predicted nuclear localization sequence (red highlight) and the location of the C-terminal deletion mutants del218 (S) and del169 (A) (blue shading). b Left: Cellular localization of full-length, del218 and del169 GFP-tagged PHF11 proteins in HEK cells. Right: plot of pixel density across cells expressing full-length or deletion mutants of PHF11. The position of the nucleus is indicated and the vertical axis indicates the pixel density (arbitrary units) 


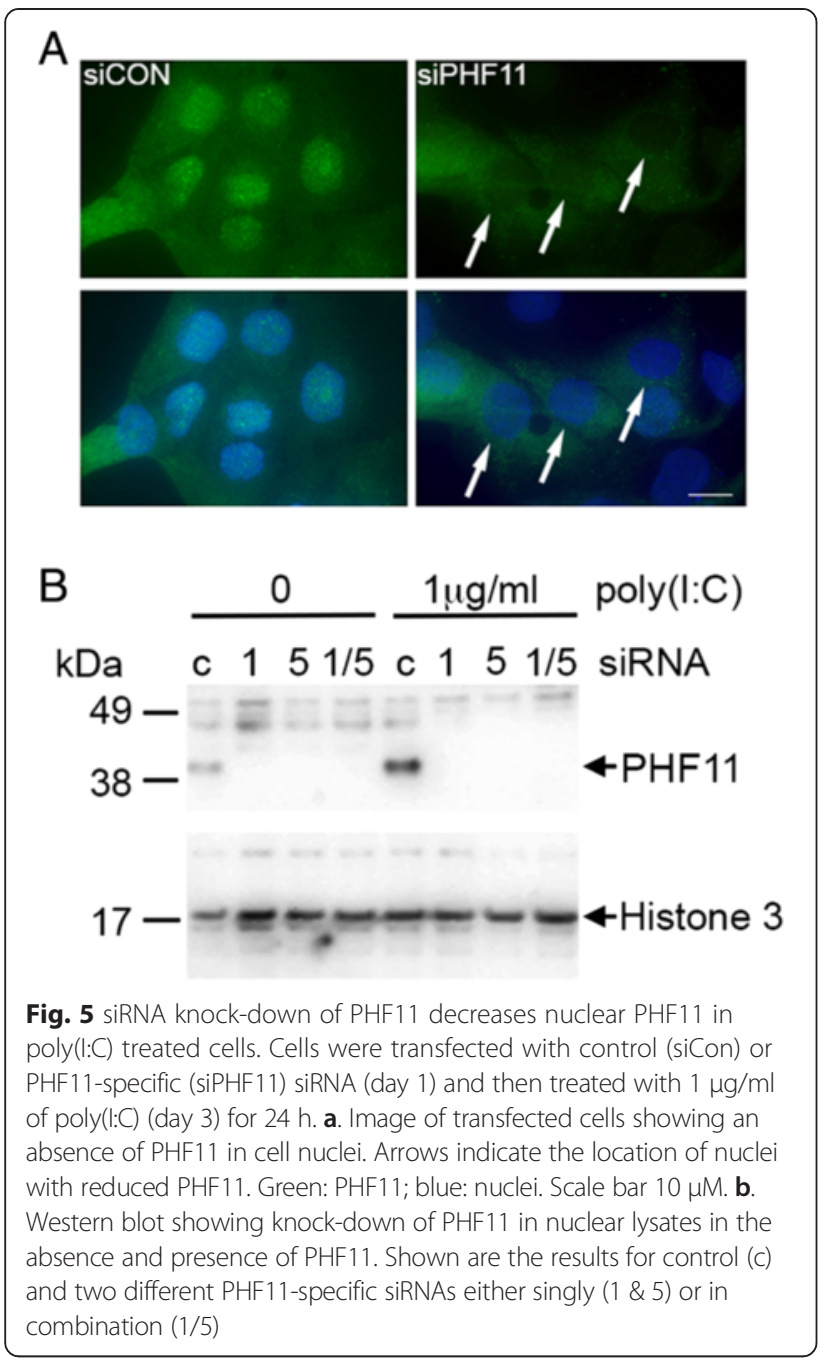

in a loss of nuclear PHF11 (Fig. 5a). Western blot analysis detected an approximately $40 \mathrm{kDa}$ PHF11-specific band in control siRNA transfected nuclei that increased following treatment with poly(I:C) (Fig. 5b, siRNA c) Two PHF11specific siRNAs ( $1 \& 5$, Fig. 5 b) were equally efficient at knocking-down PHF11 when transfected singly or in combination (Fig. 5b, 1/5). All siRNA experiments described in this paper use the combination of PHF11-specific siRNA 1 and 5.

We next examined the expression and localization of the tight junction marker claudin-1 in siRNA-transfected cells. In cells transfected with control siRNA and cultured for a total of 4 days but not treated with poly(I:C), claudin-1 immuno-reactivity was visible at the membrane with some cells displaying intense intracellular claudin-1 immuno-reactivity (Fig. 6a, untreated). Treatment with poly(I:C) resulted in increased intracellular claudin-1, as well as the appearance of claudin- 1 in the nucleus (Fig. 6a, +poly(I:C)). In parallel cultures transfected with

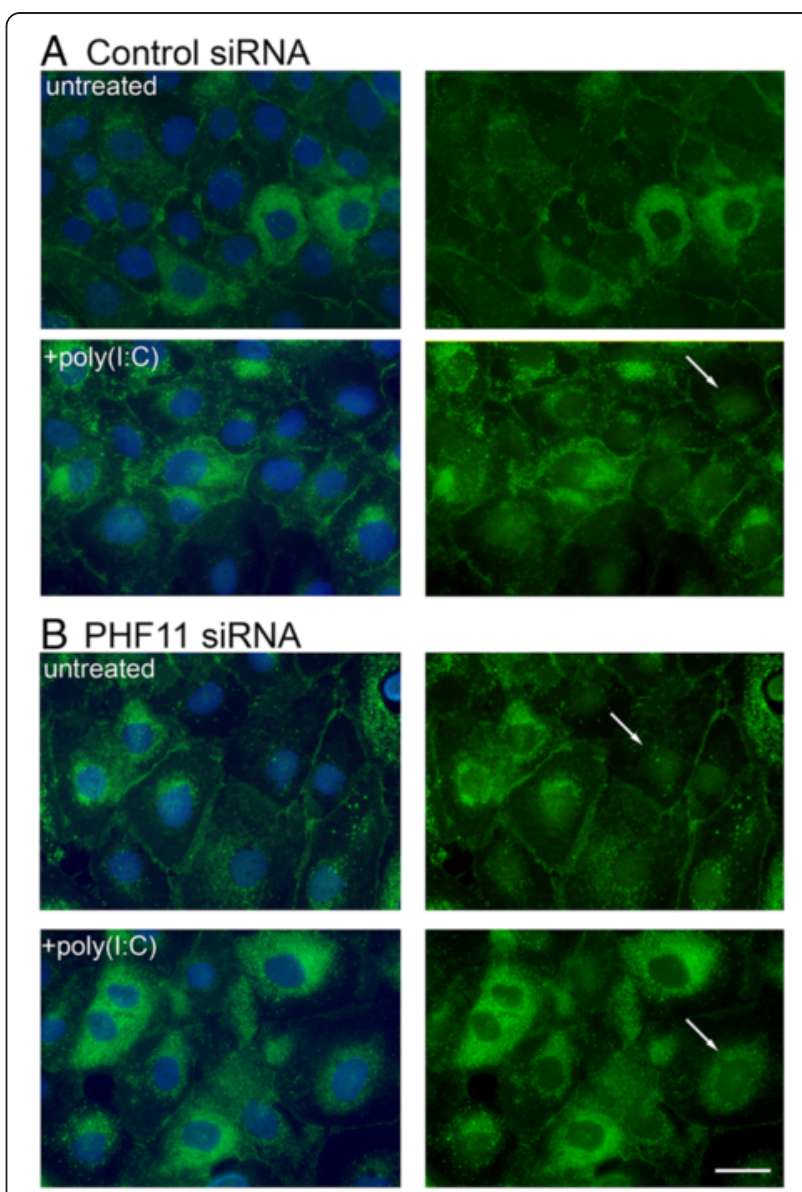

Fig. 6 Knock-down of PHF11 increases nuclear claudin-1. Cells were transfected with either: $\mathbf{a}$. control (control siRNA) or $\mathbf{b}$. a mixture of PHF11 siRNA_1 \& 5 (PHF11 siRNA) and left untreated or treated on day 3 with $1 \mathrm{mg} / \mathrm{ml}$ poly $(\mathrm{l}: \mathrm{C})$ for $24 \mathrm{~h}$ and analyzed immediately thereafter. Shown are representative images of claudin-1 and nuclei (left hand column) or claudin-1 only (right hand column) from one of three independent experiments. Green: claudin-1; blue: nuclei. Arrows indicate nuclear claudin-1. Scale bar 20 mM

PHF11-specific siRNA but not treated with poly(I:C), there was an increase in intracellular claudin-1 as well as evidence of nuclear claudin-1 (Fig. 6b, untreated). Treatment of cells transfected with PHF11-specific siRNA with poly(I:C) reduced membrane claudin-1 and increased the number of cells displaying intracellular claudin-1 immuno-reactivity (Fig. 6b, +poly(I:C)).

Assaying poly(I:C)-dependent gene expression showed there was no difference in the expression of ISG15 between cells transfected with either control or PHF11specific siRNA and this was independent of treatment with poly(I:C) (data not shown). However, knock-down of PHF11 expression resulted in an approximately 2-fold greater increase in poly(I:C)-dependent IL8 expression $24 \mathrm{~h}$ after adding poly(I:C) (Fig. 7a, $4.7 \pm 0.2$ Vs $2.1 \pm 1.2$, respectively), relative to cells transfected with control 


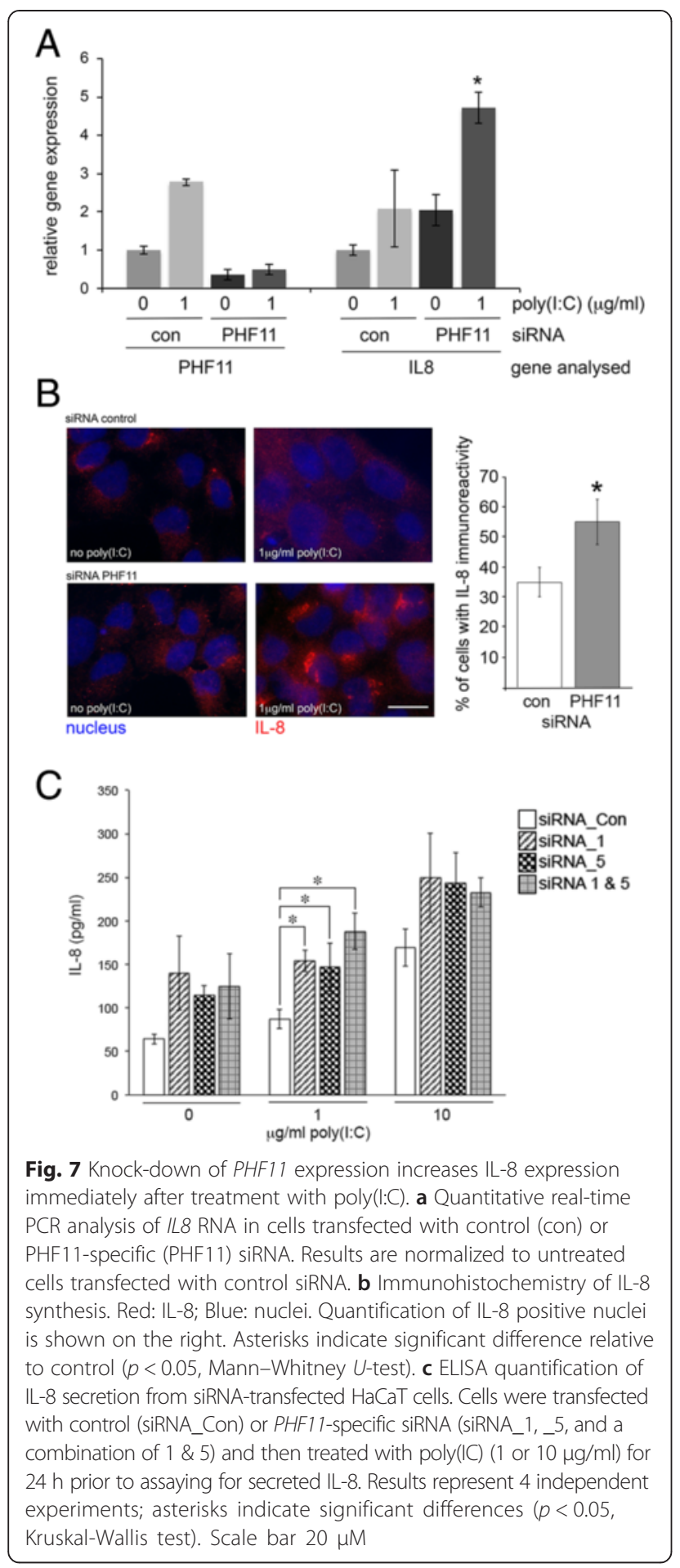

siRNA. The expression of IL-8 in cells transfected with control or PHF11-specific siRNA was next assayed by immuno-fluorescent imaging of monensin-treated cells and by quantitative ELISA. Analysis of fixed, monensintreated cells revealed a significant increase in IL8 immunoreactivity in cells transfected with PHF11-specific siRNA (Fig. 7b). Quantitative ELISA analysis of IL-8 secretion from siRNA-transfected $\mathrm{HaCaT}$ cells showed knock-down of PHF11 resulted in a significant 1.8 to 2.1 -fold increase in IL-8 secretion at $1 \mu \mathrm{g} / \mathrm{ml}$ of poly(I:C) (Fig. 7c). Knockdown of PHF11 also resulted in a non-significant 1.5-fold increase in secretion of IL-8 in HaCaT cells treated with $10 \mu \mathrm{g} / \mathrm{ml}$ of poly(I:C), relative to control siRNA (Fig. 7c).

\section{siRNA knock-down of PHF11: analysis 3 days after poly $(\mathrm{l}: \mathrm{C})$ treatment}

We first ascertained whether any differences could be detected in PHF11 expression between cells transfected with control and PHF11-specific siRNA at day 7 in culture (3 days after withdrawal of poly(I:C)). In cells that had been transfected with control siRNA, nuclear accumulation of PHF11 was still evident against a background of PHF11 expression (Fig. 8, Left hand panels). In contrast, cells that had been transfected with PHF11specific siRNA show a uniform level of PHF11 expression with no evidence of concentration in the nucleus (Fig. 8, Right hand panels).

After 7 days in culture, claudin- 1 immunoreactivity was clearly visible at the cell membrane of cells transfected with control siRNA with this distribution independent of prior treatment with poly(I:C) (Fig. 9a, control siRNA). Knock-down of PHF11 RNA resulted in decreased cell density and increased cell size while claudin-1 immunoreactivity at the membrane exhibited a more irregular appearance when compared to cells transfected with control siRNA (Fig. 9a \& b, boxed and enlarged areas). Both effects were independent of prior treatment with poly(I:C) (Fig. 9b). Nuclear claudin-1 immunoreactivity was also observed in cells transfected with PHF11-specific siRNA with nuclear claudin-1 was observed more frequently in cells treated with poly(I:C) (Fig. 9b, PHF11 siRNA, asterisks). No difference in the expression of IL-8 was observed between control and PHF11-specific siRNA 3 days after the withdrawal of poly(I:C) (data not shown).

An analysis of cell number in cultures transfected with control or PHF11-specific siRNA, and treated or not treated with poly(I:C), showed no difference in cell numbers on day 4 of culture (Fig. 10a, 4 days in culture). However, relative to day 4 , on day 7 of culture there was a greater than 2.5 -fold increase in cell number for cultures transfected with control siRNA but not treated with poly(I:C), with a smaller 1.7 -fold increase in cell number when treated with poly(I:C) (Fig. 10a, 4 \& 7 days in culture, con siRNA). In contrast, for cultures transfected with PHF11-specific siRNA there was no significant increase in cell number, irrespective of treatment with poly(I:C) (Fig. 10a, 4 \& 7 days in culture, PHF11 siRNA). To investigate this further, we next analyzed the cell cycle distribution of cells transfected with control or PHF11-specific siRNA. 


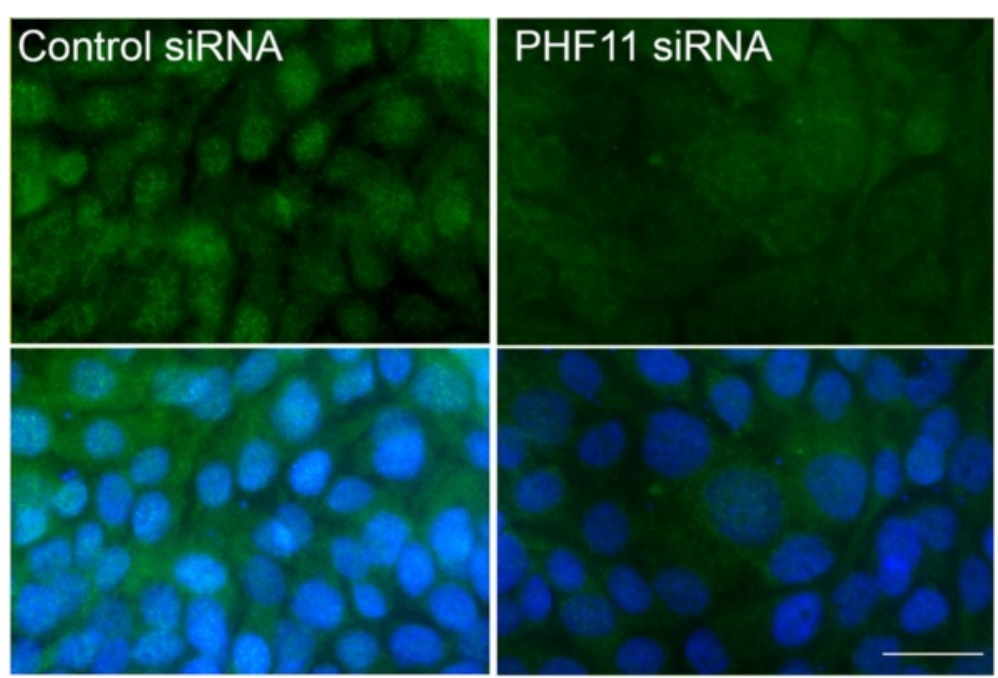

Fig. 8 PHF11 expression in siRNA-transfected cells on day 7 of culture, 3 days after withdrawal of poly(l:C). Left panels: cells transfected with control siRNA; Right panels: cells transfected with PHF11-specific siRNA. Green: PHF11; Blue: nuclei. Scale bar $20 \mu \mathrm{M}$

After 4 days in culture there was no difference in the cell cycle distribution of cells transfected with either control or PHF11-specific siRNA or between cultures treated or not treated with poly(I:C) (Fig. 10b, 4 days in culture). After 7 days in culture there was an increase in the percent of cells in G1 phase in cells transfected with control siRNA that was independent of poly(I:C) treatment (Fig. 10b, siRNA con, 4 Vs 7 days in culture: no poly(I:C), $57.8 \pm 1.9 \mathrm{Vs} 74.7 \pm 3 ; 1 \mu \mathrm{g} / \mathrm{ml}$ poly(I:C), $55.8 \pm 1$ Vs $76.5 \pm 1$ ). In contrast, transfection with PHF11-specific siRNA resulted in significantly fewer cells in G1 after 7 days in culture in culture not treated or treated with poly(I:C) (Fig. 10b, siRNA PHF11, 7 days in culture: no poly(I:C), $59.4 \pm 2 ; 1 \mu \mathrm{g} / \mathrm{ml}$ poly(I:C), $66.1 \pm 1.3)$.

\section{Discussion}

Extending on our previous work showing increased nuclear localization of PHF11 in activated T-cells [2], we show here that stimulation of $\mathrm{HaCaT}$ keratinocytes by poly(I:C) increased PHF11 RNA as well as the nuclear localization of PHF11. The distribution of PHF11 between the cytoplasm and the nucleus was dependent upon a region that included a putative NLS that was distinct from the single PHD finger. Knock-down of PHF11 led to an increase in IL-8 expression immediately following poly(I:C) treatment. A decrease in cell number, redistribution of claudin- 1 within the cell membrane and an increased frequency of claudin- 1 in the nucleus was seen three days after the withdrawal of poly(I:C).

In the $\mathrm{HaCaT}$ cell line, poly(I:C) induces apoptosis in a caspase- 8 dependent manner [32], as well as inducing the transcription and synthesis of IL-8 [23]. Normal keratinocytes and the $\mathrm{HaCaT}$ cell line synthesize IL-8 and express the IL-8 receptors CXCR1 and CXCR2 [36, 37], allowing IL-8 to act as an autocrine factor for keratinocyte migration and proliferation [36], in addition to promoting the recruitment of neutrophils to a wound site [38]. The binding of dsRNA to TLR3 on keratinocytes initiates signaling pathways that include the activation of the NF$\mathrm{kB}$ transcription factor as well as anti-viral interferondependent pathways. The cellular response to intracellular influenza A virus and extracellular poly $(\mathrm{I}: \mathrm{C})$ is very similar in lung epithelial cells, although adding poly(I:C) directly to the cell culture media, as was done in the study reported here, may also mimic the release endogenous cellular or viral dsRNA from damaged cells and the activation of TLR3 [39].

Consistent with a pro-inflammatory and pro-apoptotic role for poly $(\mathrm{I}: \mathrm{C})$ on cultured keratinocytes, poly(I:C) treatment leads to the loss of tight junctions from airway epithelial cells [40]. However, poly(I:C) also increases the expression of genes involved in skin barrier formation in cultured keratinocytes [25], while topical application of poly $(\mathrm{I}: \mathrm{C})$ accelerates wound healing in mice through the production of CXCL2 and the recruitment of neutrophils and macrophages to the wounded site [41]. Given the range of these effects and their importance to epithelial damage and repair, it is important to identify genes involved in TLR3-dependent signaling pathways that mediate the response to poly(I:C).

In experiments described here, $\mathrm{HaCaT}$ cells were transfected with siRNA and then two days later treated with poly(I:C) for $24 \mathrm{~h}$, with knock-down of PHF11 expression correlated with an increase in poly(I:C)-dependent IL8 expression. Three days after withdrawal of poly(I:C) we observed marked differences in the appearance of cultures 

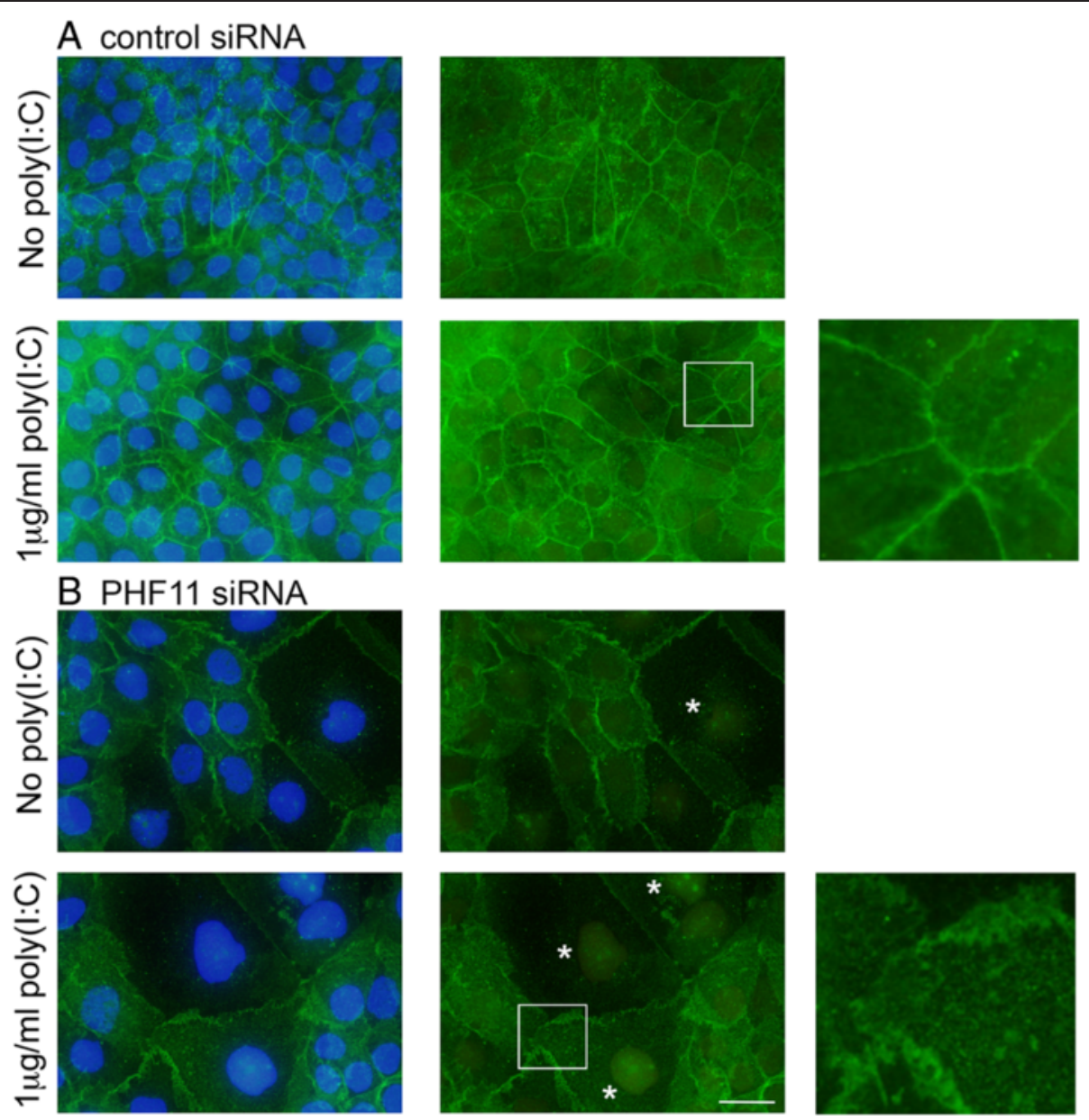

Fig. 9 Distribution of claudin-1 in siRNA transfected cells after 7 days in culture. Cells were transfected with control or PHF11-specific siRNA as already described, treated with poly(l:C) and analyzed 3 days thereafter (a total of 7 days in culture; see Fig. 1). Enlarged images of the boxed areas are shown on the right of the figure and nuclei showing claudin-1 immuno-reactivity are indicated by asterisks. Shown are representative images of three independent experiments. Green: claudin-1; blue: nuclei. Scale bar $20 \mu \mathrm{M}$

transfected with control or PHF11-specific siRNA. The distribution of membrane-localized claudin-1 in cells transfected with PHF11-specific siRNA was discontinuous and irregular and was highly reminiscent of the "zigzag" structure of tight junctions described at the junction of two motile cells by Matsuda and co-workers [42]. We also noted the appearance of nuclear claudin-1, accompanied by a significant decrease in both cell number and the proportion of cells in G1, as well as an increase in nuclear and cytoplasmic volume that is a feature of the progression of cells through the cell cycle [43]. Significantly, neither the change in claudin-1 distribution, nor the decrease in cell number seen in cells transfected with PHF11-specific siRNA was dependent on prior treatment with poly(I:C).

Colon carcinoma cells show an increase in the cytoplasmic expression and nuclear localization of claudin1 in primary tumours and metastases and knock-down of claudin-1 expression in cultured cell lines inhibits cell migration [44]. Several other membrane and tightjunction proteins also traffic between the membrane and the nucleus; the protein Zona Occludens 2 (ZO-2) interacts with several transcription factors and structural proteins in the nucleus to regulate cell growth and proliferation (for review see [45]). The exact role of claudin-1 in the nucleus is not known. We suggest that the change in cellular distribution of claudin-1 in $\mathrm{HaCaT}$ cells transfected with PHF11-specific siRNA might not be a direct effect of PHF11 knock-down, but is instead a result of differences in cell proliferation between cells transfected with control or PHF11-specific siRNA.

A genome-wide screen using RNA-interference gene knock-down was recently carried out in mice to identify genes involved in normal and oncogenic growth during skin development. This analysis identified PHF11 as one of 1800 genes considered essential for normal 

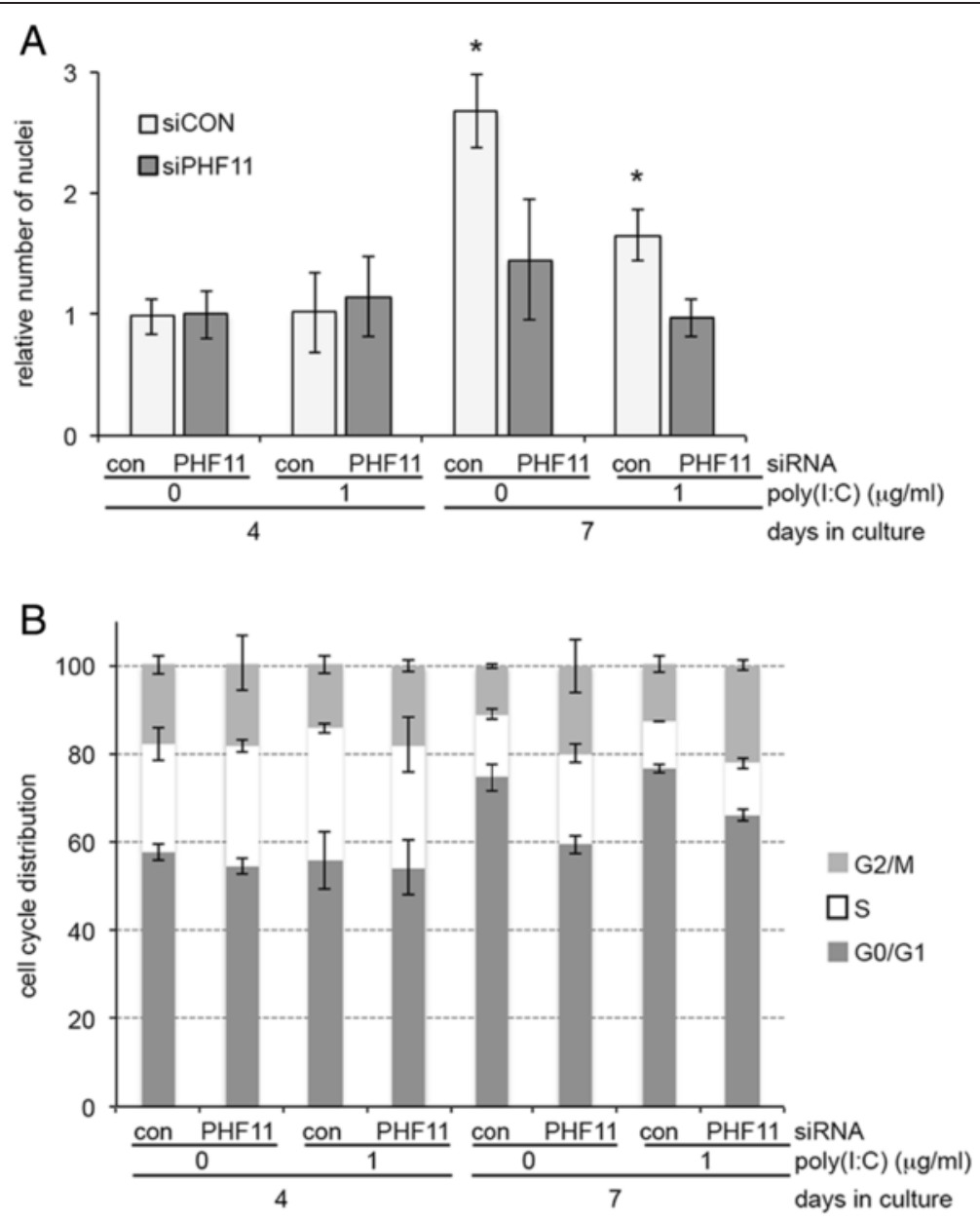

Fig. 10 Knock-down of PHF11 expression decreases cell number and the proportion of cells in the G1 phase of the cell cycle on day 7 of culture. a Cell number normalized to untreated cultures on day 4. b Cell cycle analysis of siRNA transfected cells in the treated or untreated with poly(l:C) on day 4 or 7 of culture. Con: control siRNA; PHF11: PHF11-specific siRNA. Results are from 3 independent experiments and show average \pm standard deviation, asterisks indicate significant difference relative to control $(p<0.05$, Mann-Whitney U-test)

growth [46]. It is interesting to note that an allele in the 3' untranslated region of PHF11 that is associated with asthma and dermatitis [5] reduces the expression of PHF11 [1, 7] and that this is correlated with reduced binding of the transcription factor Oct-1 [7], which is highly expressed in epithelial cells. In experiments described here, we suggest that siRNA knockdown of PHF11 expression led to a reduction in cell viability [2] and/or a slowing of cell proliferation that resulted in a sub-confluent monolayer at day 7 of culture, resulting in fewer cells arrested at G1 in the cell cycle at his time point.

In T-cells, PHF11 is a transcriptional co-activator of NF$\kappa \mathrm{B}$, with knock-down of PHF11 associated with decreased binding of NF-kB to the IFNG promoter and decreased NF- $\kappa B$-dependent transcription $[1,2]$. Over-expression of PHF11 increased class-switch recombination to IgE in activated B-cells and this was correlated with increased binding of NF- $\kappa B$ [3]. Epidermal inflammation is regulated by NF-kB-dependent cross-talk between keratinocytes and infiltrating immune cells, while epidermal hyperplasia can be induced by dysregulation of NF- $\mathrm{kB}$ in keratinocytes alone [47]. It has been shown that NF- $\mathrm{BB}$ is constitutively active in $\mathrm{HaCaT}$ keratinocytes, resulting in increased apoptosis in response to ultraviolet light [48]. Despite the constitutive activation of NF- $\mathrm{kB}$ in $\mathrm{HaCaTs}$, the sensitivity of this cell line to apoptotic stimuli is thought to reflect low NF- $\mathrm{kB}$ transcriptional activation [49]. As PHF11 potentiates NF- $\mathrm{B}$ regulated transcription in lymphocytes $[1,2]$, the reason for the increase in IL8 RNA associated with knock-down of PHF11 in $\mathrm{HaCaT}$ cells is less clear, given that IL8 expression is increased in $\mathrm{HaCaT}$ keratinocytes through an NF-kBdependent pathway [50]. Significantly, a microarray analysis of poly(I:C)-stimulated THP-1 monocytes also showed an increase in IL8 RNA following PHF11 knock- 
down (G. Jones, unpublished data), supporting the idea that PHF11 may be a negative regulator of poly(I:C)-induced IL8 expression.

In this regard it is interesting to note that PHF11 is adjacent to the gene SETDB2 that encodes a histone methyltransferase that increases histone methylation on lysine 9 of histone 3 [51], a histone modification involved in gene repression. A co-transcript that may express a PHF11/SETDB2 fusion protein has been reported in mouse [52] and human [53] cells. We are currently investigating whether epithelial cells express such a transcript and whether this transcript would include a functional histone methyltransferase domain.

\section{Conclusions}

This report describes the regulation of PHF11 by poly(I:C) in the $\mathrm{HaCaT}$ keratinocyte cell line and is consistent with other reports showing PHF11 is an interferon stimulated gene that is induced by viral infection. Given that the knock-down of PHF11 expression in HaCaT keratinocytes led to an increase in IL-8 expression immediately after poly $(\mathrm{I}: \mathrm{C})$ treatment whereas the change in cell number and the cellular distribution of claudin-1 occurred later and were independent of poly(I:C), PHF11 may have several roles in the epithelial response to infection and injury.

\section{Abbreviations}

IgE: immunoglobulin E; PHF11: plant homeodomain finger protein 11; TLR3: Toll-like receptor 3; IL-8: interleukin-8; poly(l:C): Polyinosinic:Polycytidylic Acid.

\section{Competing interests}

None of the authors have any competing financial or non-financial interests relating to the content of this manuscript.

\section{Authors' contributions}

PM developed the model for HaCaT culture, performed siRNA experiments and the localization of claudin-1 and PHF11. KM made the initial findings on the regulation of PHF11 by poly(l:C), KP performed cell cycle analysis, HC provided data for IL-8 expression and GJ designed the study, verified all analyses and wrote the manuscript. All authors read and approved the final manuscript.

\section{Funding for this project}

This project was funded by a Research Project Grant awarded to Dr Graham Jones from the School of Science and Health, Western Sydney University.

\section{Author details}

'School of Science and Health, Western Sydney University, Locked Bag 1797, 2751 Penrith, NSW, Australia. ${ }^{2}$ Present address: Garvan Institute for Medical Research, Darlinghurst, NSW, Australia.

Received: 14 April 2015 Accepted: 5 November 2015 Published online: 14 November 2015

\section{References}

1. Clarke E, Rahman N, Page N, Rolph MS, Stewart GJ, Jones GJ. Functional characterization of the atopy-associated gene PHF11. J Allergy Clin Immunol. 2008;121:1148-54.

2. Rahman N, Stewart G, Jones G. A role for the atopy-associated gene PHF11 in T-cell activation and viability. Immunol Cell Biol. 2010;88:817-24.
3. Ikari J, Inamine A, Yamamoto T, Watanabe-Takano H, Yoshida N, Fujimura L, et al. Plant homeodomain finger protein 11 promotes class switch recombination to IgE in murine activated B cells. Allergy. 2014;69:223-30.

4. Harding HP, Zhang Y, Zeng H, Novoa I, Lu PD, Calfon M, et al. An integrated stress response regulates amino acid metabolism and resistance to oxidative stress. Mol Cell. 2003;11:619-33.

5. Jang N, Stewart G, Jones G. Polymorphisms within the PHF11 gene at chromosome $13 q 14$ are associated with childhood atopic dermatitis. Genes Immun. 2005;6:262-4.

6. Gao J, Li W, Willis-Owen SA, Jiang L, Ma Y, Tian X, et al. Polymorphisms of PHF11 and DPP10 are associated with asthma and related traits in a Chinese population. Respiration. 2010;79:17-24.

7. Holt RJ, Zhang Y, Binia A, Dixon AL, Vandiedonck C, Cookson WO, et al. Allele-specific transcription of the asthma-associated PHD finger protein 11 gene (PHF11) modulated by octamer-binding transcription factor 1 (Oct-1). J Allergy Clin Immunol. 2011;127:1054-62.

8. Jones G, Stewart G. Association of PHF11 polymorphisms with asthma and allergy. Thorax. 2010;65:659-60.

9. Brown SJ, McLean WH. One remarkable molecule: filaggrin. J Invest Dermatol. 2012;132:751-62.

10. Palmer $C N$, Irvine AD, Terron-Kwiatkowski A, Zhao $Y$, Liao H, Lee SP, et al. Common loss-of-function variants of the epidermal barrier protein filaggrin are a major predisposing factor for atopic dermatitis. Nat Genet. 2006;38:441-6.

11. Weidinger S, Illig T, Baurecht H, Irvine AD, Rodriguez E, Diaz-Lacava A, et al. Loss-of-function variations within the filaggrin gene predispose for atopic dermatitis with allergic sensitizations. J Allergy Clin Immunol. 2006;118:214-9.

12. Gruber R, Elias PM, Crumrine D, Lin TK, Brandner JM, Hachem JP, et al. Filaggrin genotype in ichthyosis vulgaris predicts abnormalities in epidermal structure and function. Am J Pathol. 2011;178:2252-63.

13. Flohr C, England K, Radulovic S, McLean WH, Campbel LE, Barker J, et al. Filaggrin loss-of-function mutations are associated with early-onset eczema, eczema severity and transepidermal water loss at 3 months of age. Br J Dermatol. 2010;163:1333-6.

14. Esparza-Gordillo J, Weidinger S, Folster-Holst R, Bauerfeind A, Ruschendorf F, Patone $\mathrm{G}$, et al. A common variant on chromosome 11q13 is associated with atopic dermatitis. Nat Genet. 2009;41:596-601.

15. Ferreira MA, Matheson MC, Duffy DL, Marks GB, Hui J, Le Souef $P$, et al. Identification of IL6R and chromosome 11q13.5 as risk loci for asthma. Lancet. 2011;378:1006-14.

16. Bonnelykke K, Matheson MC, Pers TH, Granell R, Strachan DP, Alves AC, et al. Meta-analysis of genome-wide association studies identifies ten loci influencing allergic sensitization. Nat Genet. 2013;45:902-6.

17. Brown LA, Irving J, Parker R, Kim H, Press JZ, Longacre TA, et al. Amplification of EMSY, a novel oncogene on 11q13, in high grade ovarian surface epithelial carcinomas. Gynecol Oncol. 2006;100:264-70.

18. Hughes-Davies L, Huntsman D, Ruas M, Fuks F, Bye J, Chin SF, et al. EMSY links the BRCA2 pathway to sporadic breast and ovarian cancer. Cell. 2003;115:523-35

19. Howell MD, Kim BE, Gao P, Grant AV, Boguniewicz M, Debenedetto A, et al. Cytokine modulation of atopic dermatitis filaggrin skin expression. J Allergy Clin Immunol. 2007;120:150-5.

20. De Benedetto A, Rafaels NM, McGirt LY, Ivanov Al, Georas SN, Cheadle C, et al. Tight junction defects in patients with atopic dermatitis. J Allergy Clin Immunol. 2011;127:773-86.

21. Wollenberg A, Wetzel S, Burgdorf WH, Haas J. Viral infections in atopic dermatitis: pathogenic aspects and clinical management. J Allergy Clin Immunol. 2003:112:667-74.

22. Boguniewicz M, Leung DY. Recent insights into atopic dermatitis and implications for management of infectious complications. J Allergy Clin Immunol. 2010;125:4-13. quiz 14-15.

23. Kollisch G, Kalali BN, Voelcker V, Wallich R, Behrendt H, Ring J, et al. Various members of the Toll-like receptor family contribute to the innate immune response of human epidermal keratinocytes. Immunology. 2005;114:531-41.

24. Borkowski AW, Kuo IH, Bernard JJ, Yoshida T, Williams MR, Hung NJ, et al. Toll-like receptor 3 activation is required for normal skin barrier repair following UV damage. J Invest Dermatol. 2014;135(2):569-78.

25. Borkowski AW, Park K, Uchida Y, Gallo RL. Activation of TLR3 in keratinocytes increases expression of genes involved in formation of the epidermis, lipid accumulation, and epidermal organelles. J Invest Dermatol. 2013;133:2031-40. 
26. Gupta N, Rao PV. Transcriptomic profile of host response in Japanese encephalitis virus infection. Virol J. 2011;8:92.

27. Reemers SS, van Leenen D, Koerkamp MJ, van Haarlem D, van de Haar P, van Eden W, et al. Early host responses to avian influenza A virus are prolonged and enhanced at transcriptional level depending on maturation of the immune system. Mol Immunol. 2010;47:1675-85.

28. Yuan J, Cahir-McFarland E, Zhao B, Kieff E. Virus and cell RNAs expressed during Epstein-Barr virus replication. J Virol. 2006;80:2548-65.

29. Karki S, Li MM, Schoggins JW, Tian S, Rice CM, MacDonald MR. Multiple interferon stimulated genes synergize with the zinc finger antiviral protein to mediate anti-alphavirus activity. PLoS One. 2012;7:e37398.

30. Kasper CA, Sorg I, Schmutz C, Tschon T, Wischnewski H, Kim ML, et al. Cell-cell propagation of NF-kappaB transcription factor and MAP kinase activation amplifies innate immunity against bacterial infection. Immunity. 2010;33:804-16.

31. Lee KH, Cho KA, Kim JY, Kim JY, Baek JH, Woo SY, et al. Filaggrin knockdown and Toll-like receptor 3 (TLR3) stimulation enhanced the production of thymic stromal lymphopoietin (TSLP) from epidermal layers. Exp Dermatol. 2011;20:149-51.

32. Weber A, Kirejczyk Z, Besch R, Potthoff S, Leverkus M, Hacker G. Proapoptotic signalling through Toll-like receptor-3 involves TRIF-dependent activation of caspase- 8 and is under the control of inhibitor of apoptosis proteins in melanoma cells. Cell Death Differ. 2010:17:942-51.

33. Memet S, Besancon F, Bourgeade MF, Thang MN. Direct induction of interferon-gamma- and interferon-alpha/beta-inducible genes by double-stranded RNA. J Interferon Res. 1991;11:131-41.

34. Koria P, Andreadis ST. Epidermal morphogenesis: the transcriptional program of human keratinocytes during stratification. J Invest Dermatol. 2006:126:1834-41.

35. Kosugi S, Hasebe M, Tomita M, Yanagawa H. Systematic identification of cell cycle-dependent yeast nucleocytoplasmic shuttling proteins by prediction of composite motifs. Proc Natl Acad Sci U S A. 2009;106:10171-6.

36. Kroeze KL, Boink MA, Sampat-Sardjoepersad SC, Waaijman T, Scheper RJ, Gibbs S. Autocrine regulation of re-epithelialization after wounding by chemokine receptors CCR1, CCR10, CXCR1, CXCR2, and CXCR3. J Invest Dermatol. 2012;132:216-25.

37. Tang L, Yu Y, Chen J, Li Q, Yan M, Guo Z. The inhibitory effect of VitD3 on proliferation of keratinocyte cell line HACAT is mediated by downregulation of CXCR2 expression. Clin Exp Dermatol. 2003;28:416-9.

38. Roupe KM, Nybo M, Sjobring U, Alberius P, Schmidtchen A, Sorensen OE. Injury is a major inducer of epidermal innate immune responses during wound healing. J Invest Dermatol. 2010;130:1167-77.

39. Guillot L, Le Goffic R, Bloch S, Escriou N, Akira S, Chignard M, et al. Involvement of toll-like receptor 3 in the immune response of lung epithelial cells to double-stranded RNA and influenza A virus. J Biol Chem. 2005;280:5571-80.

40. Rezaee F, Meednu N, Emo JA, Saatian B, Chapman TJ, Naydenov NG, et al. Polyinosinic:polycytidylic acid induces protein kinase D-dependent disassembly of apical junctions and barrier dysfunction in airway epithelial cells. J Allergy Clin Immunol. 2011;128:1216-24.

41. Lin $\mathrm{Q}$, Wang $\mathrm{L}$, Lin $\mathrm{Y}$, Liu $X$, Ren $X$, Wen $\mathrm{S}$, et al. Toll-like receptor 3 ligand polyinosinic:polycytidylic acid promotes wound healing in human and murine skin. J Invest Dermatol. 2012;132:2085-92.

42. Matsuda M, Kubo A, Furuse M, Tsukita S. A peculiar internalization of claudins, tight junction-specific adhesion molecules, during the intercellular movement of epithelial cells. J Cell Sci. 2004;117:1247-57.

43. Maeshima K, lino H, Hihara S, Funakoshi T, Watanabe A, Nishimura M, et al. Nuclear pore formation but not nuclear growth is governed by cyclin-dependent kinases (Cdks) during interphase. Nat Struct Mol Biol. 2010;17:1065-71.

44. Dhawan P, Singh AB, Deane NG, No Y, Shiou SR, Schmidt C, et al. Claudin-1 regulates cellular transformation and metastatic behavior in colon cancer. J Clin Invest. 2005;115:1765-76.

45. Traweger A, Toepfer S, Wagner RN, Zweimueller-Mayer J, Gehwolf R, Lehner C, et al. Beyond cell-cell adhesion: Emerging roles of the tight junction scaffold ZO-2. Tissue Barriers. 2013;1:e25039.

46. Beronja S, Janki P, Heller E, Lien WH, Keyes BE, Oshimori N, et al. RNAi screens in mice identify physiological regulators of oncogenic growth. Nature. 2013;501:185-90.
47. Rebholz B, Haase I, Eckelt B, Paxian S, Flaig MJ, Ghoreschi K, et al. Crosstalk between keratinocytes and adaptive immune cells in an IkappaBalpha protein-mediated inflammatory disease of the skin. Immunity. 2007;27:296-307.

48. Lewis DA, Hengeltraub SF, Gao FC, Leivant MA, Spandau DF. Aberrant NFkappaB activity in $\mathrm{HaCaT}$ cells alters their response to UVB signaling. J Invest Dermatol. 2006;126:1885-92.

49. Chaturvedi V, Qin JZ, Denning MF, Choubey D, Diaz MO, Nickoloff BJ. Abnormal NF-kappaB signaling pathway with enhanced susceptibility to apoptosis in immortalized keratinocytes. J Dermatol Sci. 2001;26:67-78.

50. Dejean E, Foisseau M, Lagarrigue F, Lamant L, Prade N, Marfak A, et al. ALK + ALCLs induce cutaneous, HMGB-1-dependent IL-8/CXCL8 production by keratinocytes through NF-kappaB activation. Blood. 2012;119:4698-707.

51. Falandry C, Fourel G, Galy V, Ristriani T, Horard B, Bensimon E, et al. CLLD8/ KMT1F is a lysine methyltransferase that is important for chromosome segregation. J Biol Chem. 2010;285:20234-41.

52. Zhang $Y$, Dean $C$, Chessum L, Nguyen D, Stewart M, Taylor M, et al. Functional analysis of a novel ENU-induced PHD finger 11 (Phf11) mouse mutant. Mamm Genome. 2014;25:573-82.

53. Zhang $Y$, Leaves $\mathrm{NI}$, Anderson GG, Ponting CP, Broxholme J, Holt R, et al. Positional cloning of a quantitative trait locus on chromosome 13q14 that influences immunoglobulin E levels and asthma. Nat Genet. 2003;34:181-6.

\section{Submit your next manuscript to BioMed Central and take full advantage of:}

- Convenient online submission

- Thorough peer review

- No space constraints or color figure charges

- Immediate publication on acceptance

- Inclusion in PubMed, CAS, Scopus and Google Scholar

- Research which is freely available for redistribution 